Abstract THU0409 - Table 1.

\begin{tabular}{lcccccc}
\hline $\begin{array}{l}\text { BaselinelLast } \\
\text { follow-up }\end{array}$ & Number & $\%$ & ASDAS $\leq 1.3$ & $\%$ & ASDAS $\geq 1.3$ & $\%$ \\
\hline ASDAS $\leq 1.3$ & 190 & $28.49 \%$ & 122 & $64.21 \%$ & 68 & $35.79 \%$ \\
ASDAS $\geq 1.3$ & 477 & $71.51 \%$ & 154 & $32.29 \%$ & 323 & $67.71 \%$ \\
Total & 667 & $100 \%$ & 276 & $41.38 \%$ & 391 & 58.62 \\
\hline
\end{tabular}

Abstract THU0409 - Table 2.

\begin{tabular}{lcccc}
\hline $\begin{array}{l}\text { Self- } \\
\text { Assessments }\end{array}$ & Number & $\begin{array}{c}\text { Baseline (T2T } \\
\text { rate) }\end{array}$ & $\begin{array}{c}\text { Last follow-up (T2T } \\
\text { rate) }\end{array}$ & Improvement \\
\hline$\leq 3$ times & 393 & $26.97 \%$ & $35.37 \%$ & $8.40 \%$ \\
$>3$ times & 274 & $30.66 \%$ & $50.00 \%$ & $19.34 \%$ \\
\hline
\end{tabular}

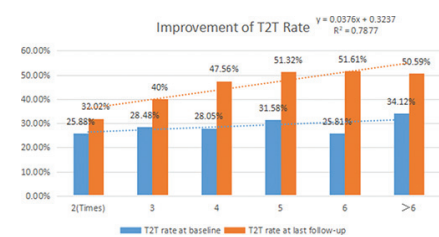

Abstract THU0409 - Figure 1

Disclosure of Interests: None declared

DOI: 10.1136/annrheumdis-2019-eular.6471

\section{THU0410 UVEITIS RELATED FACTORS IN PATIENTS WITH SPONDYLOARTHRITIS}

Nazife Sule Yasar Bilge ${ }^{1}$, Timuçin Kaşifoğlu ${ }^{1}$, Sedat Kiraz ${ }^{2}$, Ali İhsan Ertenli², Orhan Küçükșahin ${ }^{3}$, Ediz Dalkılıç ${ }^{4}$, Cemal Bes ${ }^{5}$, Nilüfer Alpay Kanıtez ${ }^{6}$, Hakan Emmungil ${ }^{7}$, Pamir Atagunduz ${ }^{8}$, Belkis Nihan Seniz ${ }^{4}$, Burcu Yağız ${ }^{4}$ Süleyman Serdar Koca ${ }^{9}$, Muhammet Cınar ${ }^{10}$, Askkın Ates ${ }^{11}$, Servet Akar ${ }^{12}$ Duygu Ersözlü ${ }^{13}$,Veli Yazisiz ${ }^{14}$, Gezmiș Kimyon ${ }^{15}$, Muge Aydın Tufan ${ }^{16}$, Ridvan Mercan ${ }^{17}$, Abdulsamet Erden ${ }^{2}$,Erdal Bodakci ${ }^{1}$, Önay Gerçik ${ }^{12}$, Burak Öz $^{9}$, Zeynel Abidin Akar ${ }^{9}$, Omer Karadag ${ }^{2}$, Bahar Dincer ${ }^{11}$, Sedat YIImaz ${ }^{10}$ Yavuz Pehlivan ${ }^{4}$, Ender Terzioğlu $^{14}$, Levent Kılıç ${ }^{2}$, Emel Gönüllü ${ }^{18}$, Sukran Erten ${ }^{19}$, Sezin Turan ${ }^{7}$, Koray Taşçוlar ${ }^{20}$, Umut Kalyoncu ${ }^{2}$. 'Eskisehir Osmangazi University, Eskişehir, Turkey; ${ }^{2}$ Hacettepe University, Ankara, Turkey; ${ }^{3}$ Liv Hospital Ankara, Ankara, Turkey; ${ }^{4}$ Uludağ University, Bursa, Turkey; ${ }^{5}$ Bakırköy Dr. Sadi Konuk Eğitim Ve Araștırma Hastanesi, Istanbul, Turkey; ${ }^{6}$ Koc Üniversitesi, Istanbul, Turkey; ${ }^{7}$ Trakya University, Edirne, Turkey; ${ }^{8}$ Marmara University, Istanbul, Turkey; ${ }^{9}$ Fırat Üniversitesi, Elazıg, Turkey; ${ }^{10}$ Gulhane Training and Research Hospital, Ankara, Turkey; ${ }^{11}$ Ankara University, Ankara, Turkey, ${ }^{12}$ Izmir Katip Çelebi University, Izmır, Turkey, ${ }^{13}$ Adana State Hospital, Adana, Turkey, ${ }^{14}$ Akdeniz Üniversitesi, Antalya, Turkey, ${ }^{15}$ Antakya State Hospital, Antakya, Turkey; ${ }^{16}$ Başkent Üniversitesi, Adana, Turkey, ${ }^{17}$ Tekirdağ Namık Kemal Üniversitesi, Tekirdag, Turkey; ${ }^{18}$ Sakarya Üniversitesi, Sakarya, Turkey; ${ }^{19}$ Atatürk Eğitim ve Araştırma Hastanesi, Ankara, Turkey; ${ }^{20}$ Istanbul, Istanbul, Turkey

Background: Uveitis is the most common extra-articular feature of spondyloarthritis $(\mathrm{SpA})$. Sometimes uveitis may be the only clinical finding of $\mathrm{SpA}$ leading to diagnosis. In the current literature, there is information about frequency and characteristics of uveitis in SpA patients; however, factors associated with uveitis are not clear $(1,2)$.

Objectives: Our aim in this study was to analyze uveitis-related factors in a large cohort of SpA patients.

Methods: This multicenter, prospective observational cohort study used the TReasure database in which web-based registration of rheumatoid arthritis and SpA patients are being performed in 15 centers across different regions of Turkey. Age, gender, duration of illness, delayed onset, SpA clinical findings, HLA B27 and acute phase responses (erythrocyte sedimentation rate and C-reactive protein, BASDAI and BASFI values, clinical findings and direct X-ray findings of SpA patients with and without uveitis were retrospectively evaluated.

Results: As of January 2019, there were 4557 registered SpA patients. Overall, $491(10.8 \%)$ patients had experienced one or more episodes of uveitis. The median (Q1-Q3) uveitis onset age was 46 years (38-53 years) and the median (Q1-Q3) uveitis attack number was 2 (1-4). Uveitis was usually unilateral $(74.2 \%)$. Records of eye damage was available in 373 patients, of whom $45(12.1 \%)$ had permanent damage in the eye. Patients with permanent eye damage had more frequent uveitis attack (3 $(2-6)$ vs. $2(1-3), p=0.003)$ and had tendency of bilateral uveitis attack $(41.5 \%$ vs $24 \%, p=0.017)$.
Duration between the first uveitis attack and onset of SpA symptoms was 68 months (7-141). On the other hand, the mean duration between the first uveitis attack and SpA diagnosis is 7 months (17-68 months). In 320 patients $(70 \%)$, uveitis was diagnosed before the onset of $\mathrm{SpA}$ symptoms and $52 \%(n=240)$ of the patients had uveitis before SpA diagnosis.

Demographic and clinical features of the patients are given in Table 1. Conclusion: In our cohort, genetic background, radiographic severity, and disease duration may be related with uveitis. HLA B27 positivity and family history may be risk factors for development of uveitis. First attack of uveitis is nearly always before the onset of symptoms and diagnosis of SpA. Although uveitis is usually self-limited; however, almost $10 \%$ of SpA patients may have permanent eye damage. Thus, patients with uveitis should be carefully investigated because it may be the diagnostic feature of SpA.

\begin{tabular}{|c|c|c|c|}
\hline \multicolumn{4}{|c|}{ llueitis (t) } \\
\hline & $\begin{array}{l}\text { Uveitis }(-) \\
n=4066\end{array}$ & $\begin{array}{c}\text { Uveitis (+) } \\
n=491\end{array}$ & $\mathbf{p}$ \\
\hline Sex $($ Male/Female, \%) & $55.6 / 44.4$ & $59.7 / 40.3$ & $0.083^{*}$ \\
\hline Age, year, median (Q1-Q3) & $42(35-50)$ & 48(38-53) & $<0.001^{*}$ \\
\hline Delay time of diagnosis, months, median (Q1-Q3) & $24\langle 5-71\rangle$ & $37(5-97)$ & $0.002^{*}$ \\
\hline Duration of disease, months, median (Q1-Q3) & $82(43-140)$ & $129(73-202)$ & $<0.001^{*}$ \\
\hline Enthesitis, n (\%) & $615(28.1\rangle$ & $83(33.5)$ & $0.075^{* *}$ \\
\hline Dactylitis, n (\%) & $178(6.6)$ & $17(5)$ & $0.252^{* *}$ \\
\hline Psoriasis, $n$ (\%) & $640(15.9)$ & $21(4.3)$ & $<0.001^{* x}$ \\
\hline HLA $827(+), n(\%)$ & $1156(49.3)$ & $218(70.6)$ & $<0.001^{* *}$ \\
\hline Family history for SpA, $n(\%)$ & $1091(29)$ & $180(40)$ & $<0.001^{* x}$ \\
\hline Sacroilititis, n (\%) & $2098(88.7)$ & $317(94.3)$ & 0.002 \\
\hline Sxndesmoghytes, n (\%) & $460(24.5)$ & $119(45.2)$ & $<0.001^{* x}$ \\
\hline Bamboo spine, $n(\%)$ & $241(11.2)$ & $70(23.1)$ & $<0.001^{* *}$ \\
\hline BASDAl, median (Q1-Q3) & $5.8(4.1-7)$ & $5.5(3.7-6.8)$ & $0.007^{*}$ \\
\hline BASFI, median (Q1-Q3) & $4.4(2.4-6.1)$ & $3.7(1.9-5.2)$ & $0.007^{*}$ \\
\hline $\mathrm{ESH}, \mathrm{mm} / \mathrm{h}$, median $(\mathrm{Q} 1-\mathrm{Q}, 3\}$ & $22(10-38)$ & $26(11-46)$ & $0.008^{*}$ \\
\hline CRP, mg/L, median (Q1-Q3) & $12.1(4.6-27.6)$ & $13.5(6.1-34)$ & $0.016^{*}$ \\
\hline
\end{tabular}

Disclosure of Interests: : Nazife Sule Yasar Bilge: None declared, Timuçin Kaşifoğlu: None declared, Sedat Kiraz: None declared, Ali İhsan Ertenli: None declared, Orhan Küçükşahin: None declared, Ediz Dalkılıç Grant/ research support from: MSD and Abbvie, Consultant for: MSD, Abbvie, Roche, UCB, Pfizer and Novartis, Speakers bureau: MSD, Abbvie, Roche UCB, Pfizer and Novartis, Cemal Bes: None declared, Nilüfer Alpay Kanıtez: None declared, Hakan Emmungil Grant/research support from: MSD Roche, Pfizer, Abbvie, Consultant for: Novartis, Roche, Speakers bureau: MSD, Roche, Pfizer, Abbvie,Celltrion, Novartis, Pamir Atagunduz: None declared, Belkis Nihan Seniz: None declared, Burcu Yağız: None declared, Süleyman Serdar Koca: None declared, Muhammet Çınar: None declared, Aşkın ATEŞ: None declared, Servet Akar: None declared Duygu Ersözlü: None declared, Veli Yazisiz: None declared, Gezmiş Kimyon: None declared, Muge Aydın Tufan: None declared, Ridvan Mercan: None declared, Abdulsamet Erden: None declared, Erdal Bodakci: None declared, Önay Gerçik: None declared, Burak Öz: None declared, Zeynel Abidin Akar: None declared, Omer Karadag: None declared, Bahar Dincer: None declared, Sedat Yılmaz: None declared, Yavuz Pehlivan: None declared, Ender Terzioğlu: None declared, Levent Kılıç: None declared, Emel Gönüllü: None declared, Sukran Erten: None declared, Sezin Turan: None declared, Koray Taşçılar: None declared, Umut Kalyoncu Grant/research support from: MSD, Roche, UCB, Novartis and Pfizer, Consultant for: MSD, Abbvie, Roche, UCB, Novartis, Pfizer and Abdi Ibrahim, Speakers bureau: MSD, Abbvie, Roche, UCB, Novartis, Pfizer and Abdi Ibrahim

DOI: 10.1136/annrheumdis-2019-eular.6147 